УДК [631.56:634.21]:678.048

(C) 2012

Соколова В. М., кандидат сільськогосподарських наук

Таврійський державний агротехнологічний університет

\title{
ІНТЕНСИВНІСТЬ ДИХАННЯ ПЛОДІВ АБРИКОСА ЗАЛЕЖНО ВІД СПОСОБУ ЇХ ОБРОБКИ АНТИОКСИДАНТНОЮ КОМПОЗИЦІЕЮ АКМ
}

\section{Рецензент - кандидат технічних наук Н. П. Загорко}

\begin{abstract}
Встановлено, щчо із досліджених способів обробки плодів абрикоса найбільш ефективним є обприскування їх розчином антиоксидантної композичії АКМ перед збиранням, яке сприяє утворенню на поверхні плоду найбільш однорідної захисної плівки товщиною 7,0-7,5 мкм та забезпечує рівномірний розподіл антиоксидантів по їх поверхні. Така обробка дозволяє в 1,4-1,5 рази знизити інтенсивність дихання плодів, відсунути на більш пізні строки настання клімактеричного підйому та, як наслідок, подовжити термін їх зберігання до 55 діб.
\end{abstract}

Ключові слова: зберігання, дихання, обприскування, занурення, антиоксиданти, плоди абрикоса.

Постановка проблеми. Особлива роль у харчуванні людини належить плодам абрикоса, завдяки їх унікальному біоактивному і мінеральному складу. Але умови їх виробництва обумовлюють сильно виражену сезонність споживання. Тому, пріоритетного значення набуває проблема подовження періоду споживання цих плодів. Шляхом вирішення проблеми є пошук нових способів підготовки і зберігання плодів абрикоса.

Аналіз досліджень і публікацій, у яких започатковано розв'язання даної проблеми. Дихання $є$ домінуючим процесом обміну речовин. Його інтенсивність прямо пропорційна метаболічній активності в різні періоди життя плодів. Будь-які екзогенні фактори впливають на рівень дихання, змінюючи при цьому якість плодів та строки їх зберігання [3]. Так, за даними вчених $[5,6,10]$ застосування обробки плодів зерняткових культур антиоксидантними препаратами дозволяє знизити інтенсивність їх дихання в період зберігання та затримати його клімактеричний підйом. Родіков С. А. [8], Яковлєва Л. А. та ін. [7], пропонують проводити обробку плодів антиоксидантними композиціями шляхом обприскування, Н. Y. Li [17], О. П. Прісс [10], О. С. Мироничева [6], А. Sardo [8] - методом занурення, G. B. Bompeix [9] - терморозпиленням. Ці способи обробки широко застосовуються для підготовки до зберігання плодів яблуні, груші, айви та деяких овочів - капусти, кабачків, картоплі і т. д. Рекомендації щодо способу обробки плодів аб- рикоса антиоксидантними композиціями та дані про зміни інтенсивності дихання плодів залежно від способу їх обробки в літературі відсутні.

Мета і завдання досліджень. Метою наших досліджень було з'ясування впливу способів обробки плодів абрикоса водними розчинами антиоксидантної композиції АКМ на зміни їх інтенсивності дихання при зберіганні.

Для досягнення цієї мети були поставлені такі завдання:

- дослідити вплив обприскування плодів перед та після збирання розчином АКМ на зміни їх інтенсивності дихання при зберіганні;

- дослідити вплив занурення плодів абрикоса у водний розчин АКМ на зміни ї інтенсивності дихання при зберіганні.

Об'єкт дослідження - процес зберігання плодів абрикоса, оброблених розчином антиоксидантної композиції АКМ.

Предмет дослідження - зміни інтенсивності дихання плодів при зберіганні за обробки розчином антиоксидантної композиції.

Матеріали і методи досліджень. Дослідження проводилися в 2006-2009 рр. на базі лабораторії «Технологія первинної переробки і зберігання продуктів рослинництва» НДІ «Агротехнологій та екології» Таврійського державного агротехнологічного університету та сільськогосподарського виробничого кооперативу ім. «Фрунзе», смт. Веселе.

У дослідженнях використовували плоди абрикоса середнього строку достигання - сорт Краснощокий та пізнього строку достигання - сорт Мелітопольський пізній, що внесені в реєстр сортів рослин України, які відбирали з 10 найбільш типових дерев кожного помологічного сорту, 3 усіх чотирьох боків і середини крони. Схема садіння дерев - 6x4, система утримання міжрядь і пристовбурних смуг - чорний пар.

Визначення календарної дати знімання проводили за такими ознаками:

- легкість відокремлення плоду від плодової гілки;

- забарвлення шкірочки та м’якуша;

- смак і соковитість; 
- щільність тканин (пенетрометром FT 011);

- кількість днів від масового цвітіння та за сумою активних температур.

Товарну обробку проводили в саду, виділяючи цілі, міцні, чисті, не уражені плоди (1-го товарного гатунку), згідно з вимогами ISO 2826-74 [2], ГОСТ 21832-76 [1] та вибраковуючи нестандартні екземпляри. Плоди укладали в дерев'яні ящикилотки №77 (IV-2) по 7 кг у кожному рядами в два шари згідно з ГОСТ 10131-93 [16].

Обробку плодів проводили способами обприскування і занурення. Для обробки застосовували воду (контроль) та дозволений до використання в сільському господарстві водний розчин комплексного антиоксидантного препарату АКМ, який $\epsilon$ композицією біологічно активних речовин антиоксидантного типу (дистинол) і суміші поліетиленгліколів (ПЕГ) з концентраціями: дистинолу $0,003 \%$; поліетиленгліколів - $1 \%$. Дистинол є комплексом антиоксидантів диметилсульфоксиду (ДМСО) та іонолу зі співвідношенням компонентів 1:1,4. В суміш поліетиленгліколів входить ПЕГ400 і ПЕГ1500 зі співвідношенням компонентів $1: 2,3$.

Зберігали абрикоси у холодильній камері КХР-6 при температурі $0 \pm 1{ }^{0} \mathrm{C}$ та відносній вологості повітря 90-95\%. Режими зберігання визначали згідно з ДСТУ 2169:2003 [14]. Досліди закладали в п’ятикратній повторності.

Відбір і підготовку проб до аналізів здійснювали згідно із ДСТУ ISO 874-2002 [15]. Інтенсивність дихання визначали за методом І. П. Толмачова [13].

Для визначення структури і товщини захисної плівки на поверхні плодів, оброблених розчином АОК-М, робили зрізи з верхньої, бокової та нижньої частин плодів абрикоса та досліджували їх за допомогою мікроскопа XSP-146TP, 3 фотометричною сіткою в окулярі, фіксуванням зрізів камерою Kodak.

Математичну обробку результатів виконували за В. Ф. Моісейченко та ін. (1996) і програмою Microsoft Office Excel 2003.

Результати досліджень. За даними наших досліджень обробка плодів абрикоса антиоксидантною композицією шляхом обприскування перед та після збирання дозволила подовжити тривалість їх зберігання до 55 діб, а занурення у розчин композиції АКМ - до 25-30 діб, залежно від сорту.

Нами було встановлено, що спосіб обприскування плодів розчином АКМ перед збиранням сприяє утворенню на поверхні плодів абрикоса плівки товщиною 7,0-7,5 мкм.

За обробки абрикосів способами обприску- вання після збирання та зануренні їх у розчин композиції не можливо досягнути рівномірного плівкоутворення по поверхні плодів. Мінімальна товщина плівки (3,0-3,5 мкм) утворювалася у місці дотику плоду до поверхні транспортера при підсушуванні.

Більш високу активність дихання на початку зберігання (рис. 1) мали плоди абрикоса сорту Краснощокий $-30,7$ мл $\mathrm{CO}_{2} /$ кг год $\left(\mathrm{t}=0{ }^{\circ} \mathrm{C}\right)$. Абрикоси сорту Мелітопольський пізній виділяли 27,9 мл $\mathrm{CO}_{2} /$ кг·год.

В контрольних варіантах після закладання плодів на зберігання інтенсивність дихання помітно підвищувалася, потім певний період часу спадала, та знову починала підвищуватись, що свідчило про процеси перезрівання. Максимальне значення інтенсивності дихання в контрольному варіанті спостерігалось на 15-ту добу з активністю дихання 94,1 та 85,5 мл $\mathrm{CO}_{2} /$ кг год відповідно для абрикосів сортів Краснощокий та Мелітопольський пізній. Плоди оброблені за варіантами 2, 3, 4 мали нижчу інтенсивність дихання протягом всього періоду зберігання, в порівнянні 3 плодами варіанта 1 (к) (рис. 1). Це пояснюється тим, що антиоксиданти, які входять до складу АКМ (дистинол), уповільнюють окиснювальні процеси в тканинах $[4,12]$. Так, за обробки плодів АКМ обприскуванням перед збиранням клімактеричний підйом дихання спостерігався на $40-$ д добу (плоди сорту Краснощокий) та на 45-ту добу (абрикоси сорту Мелітопольський пізній) зберігання. Однак навіть в цей період, активність дихання була в середньому 1,2 рази нижчою, порівняно 3 плодами без обробки.

Обробка плодів способом обприскування після збирання дозволяла відсунути клімактерикс до 40-45 діб, а інтенсивність їх дихання в цей період була лише в 1,1 рази нижчою, ніж в контрольному варіанті.

Обробка абрикосів способом занурення практично не впливала на дихальну активність. У плодів цього варіанту клімактеричний підйом спостерігався на 15-20-у добу, але інтенсивність дихання в цей період була в 1,1 рази нижчою ніж у плодів контрольного варіанту.

Висновки. Із способів обробки плодів найбільш ефективним $\epsilon$ спосіб їх обприскування на материнській рослині перед збиранням. Він забезпечує утворення на поверхні плодів найбільш рівномірної плівки товщиною 7,0-7,5 мкм, яка зменшує інтенсивність дихання плодів в 1,4-1,5 рази, дозволяє відсунути на більш пізні строки настання клімактеричного підйому та, як наслідок, подовжити термін їх зберігання. 
A

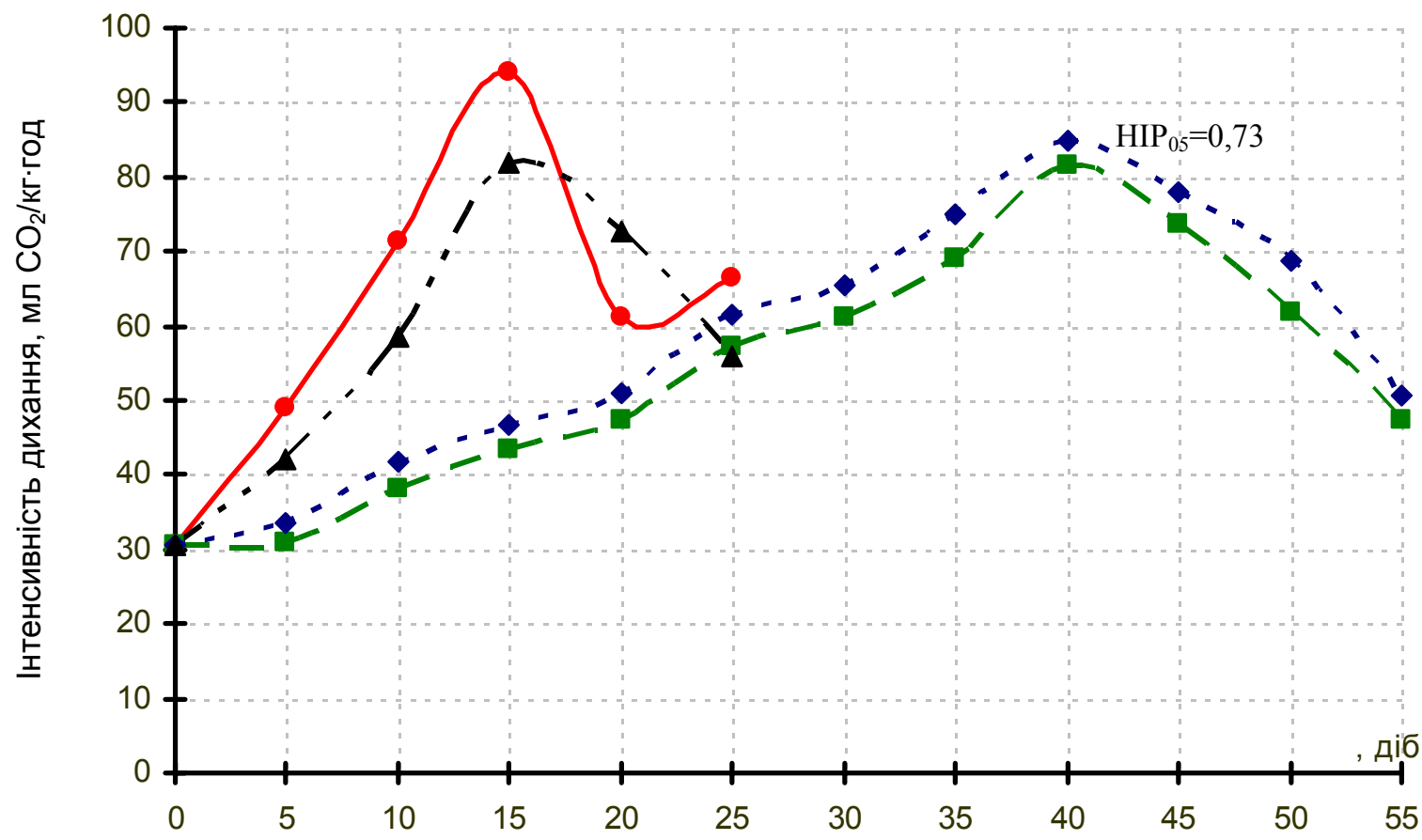

Б

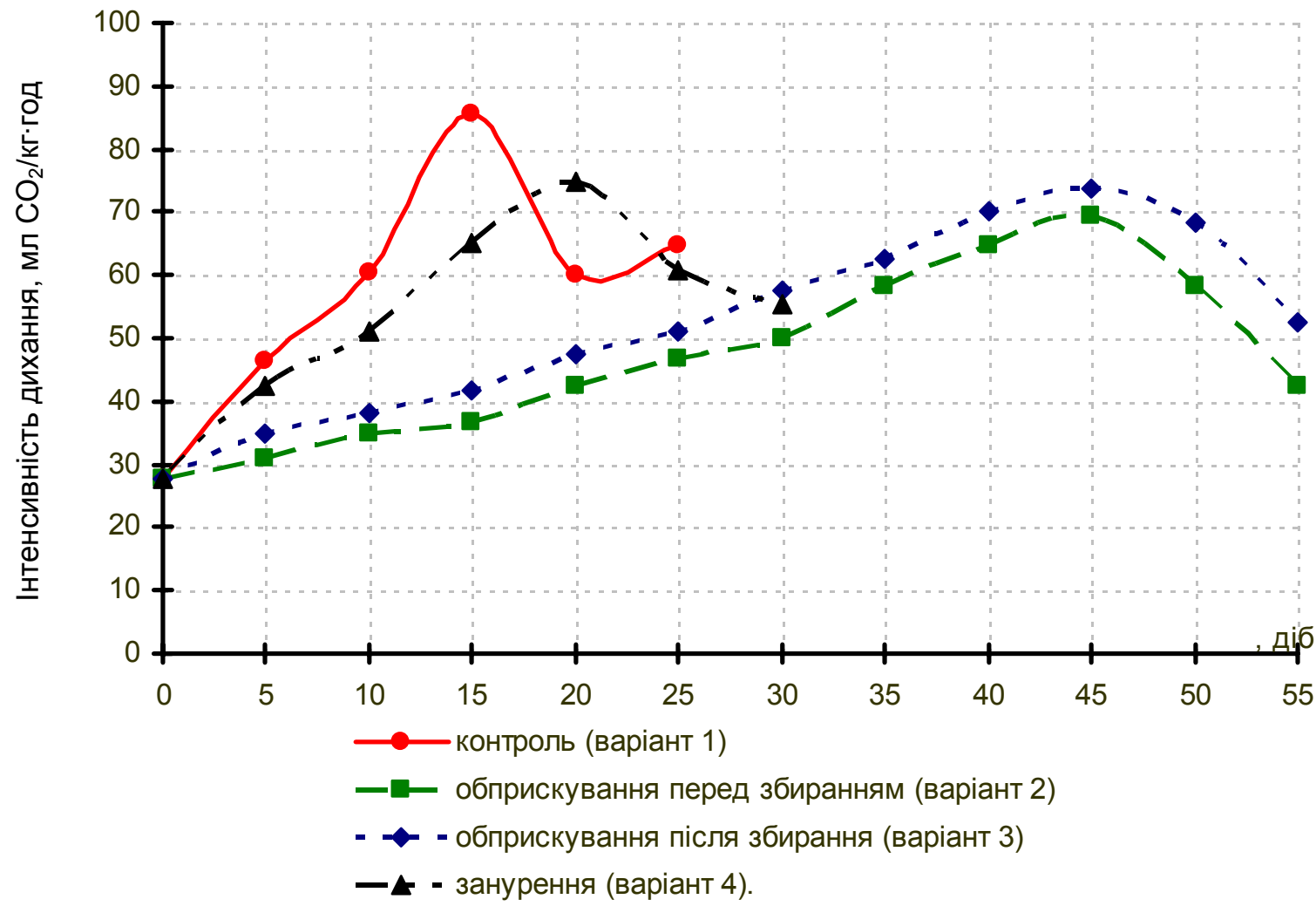

Рис. 1. Динаміка інтенсивності дихання плодів абрикоса сорту

Краснощфкий (А) та Мелітопольський пізній (Б) при зберіганні залежсно від способу їх обробки розчином композицї̈ АКМ, мл $\mathrm{CO}_{2} / \kappa 2 \cdot 2 о \partial$

Способи обприскування антиоксидантною композицією АКМ після збирання та занурення не дозволяють утворювати на поверхні плодів рівномірної плівки. Мінімальна ії товщина спостерігається у місці дотику плоду до поверхні транспортера при підсушуванні.
Виникає необхідність дослідження впливу різних концентрацій діючої речовини антиоксидантної композиції АКМ за обробки плодів абрикоса способом обприскування на материнській рослині перед збиранням та встановлення оптимальної іiі концентрації. 


\section{БІБЛІОГРАФІЯ}

1. Абрикосы свежие. Технические условия: ГОСТ 21832-76. - [Введен в действие от 1977.01.07]. - М.: Гос. комитет СССР по стандартам, 1978. - $6 \mathrm{c}$.

2. Абрикосы. Руководство по хранению в холодильных камерах: ИСО 2826-74. - [Введен в действие 10.03.93]. - М.: Издательство стандартов, $1993 .-42 \mathrm{c}$.

3. Бедин Ф. П. Технология хранения растительного сырья / Ф. П. Бедин, Е. Ф. Балан, Н. И. Чумак. - Одесса: Астропринт, 2002. - 196 с.

4. Иощенко C. E. Влияние диметилсульфоксида на тканевую енергетику / С. Е. Иощенко, В. С. Войтенко // Вопросы курортологии. 1990. - №2. - C. 62-64.

5. Ковтун M. E. Разработка новых элементов технологии длительного хранения плодов груши с применением антиоксидантов : автореф. дис. на соискание уч. степени канд. с.-х. наук : спец. 06.00.29 «Первичная обработка, хранение зерна и другой продукции растениеводства» / Ковтун Марина Егоровна. - Ялта, 1997. - 21 с.

6. Миронычева E. C. Обоснование использования антиоксидантных препаратов для длительного хранения плодов яблони : автореф. дис. на соискание уч. степени канд. с.-х. наук : 05.18.03 «Первичная обработка и хранение продукции растениеводства» / Миронычева Елена Сергеевна. - Ялта, 2002. - 18 с.

7. Пат. 2294618 Российская Федерация, МПК ${ }^{7}$ А 01 F 25/00, А $01 \mathrm{~N} \mathrm{63/00.} \mathrm{Способ} \mathrm{потготовки}$ плодов или овощей к хранению / Яковлева Л. А., Великанова Е. В., Торбин А. С., Квасенков О. И.; заявитель и патентообладатель Квасенков О. И. - № 2005122601/12; заявл. 18.07.05; опубл. 10.03.07, Бюл. № 7.

8. Пат. 2790193 Франция, МПК ${ }^{7}$ А 23 В 4/20. Procede de traitement de fruits l'association d'un terpene et d'un antioxidant / Bompeix G., Sardo A.; Xeda International SA. - № 9902465; заявл. 26.02.99; опубл. 01.09.00.

9. Пат. 2720011 Франция, МКИ ${ }^{6}$ В 01 F 17/38. Composition pour le traitement des fruits et legumes par thermonèbulisation et procèdè de traitement / Bompeix Gilber Bemard, Sardo Alberto Quintino;
Xeda International - Bompeix Gilbert Bernard. № 9406196 ; заявл. 20.05.94; опубл. 24.11.95.

10. Присс О. П. Обоснование использования нових антиоксидантних препаратов для длительного хранения яблок: автореф. дис. на соискание уч. степени канд. с.-х. наук : 05.18 .03 «Первичная обработка и хранение продукции растениеводства» / Присс Олеся Петровна. - Ялта, 2000. $15 \mathrm{c}$.

11. Родиков С. А. Опыт обработки плодов антиоксидантами перед закладкой на хранение в садоводческих хозяйствах / С. А. Родиков // Хранение и переработка сельхозсырья. - 2004. - №4. - C. 28-29.

12. Сербинова E. A. Механизмы антиоксидантного действия экранированных фенолов в биологических мембранах. Эффекты 4-метил-2,6 дитретбутилфенола (ионола) и его производных / Е. А. Сербинова, М. Харфуф, Л. Ю. Ухин // Бюл. экспер. биол. и медицины. - 1990. - №11. C. 486-488.

13. Толмачев И. П. Определение интенсивности дыхания / И. П. Толмачев // Труды института физиологии растений им. К. А. Тимирязева. 1950. - Т. 7. - Вып. 1.

14. Фрукти й овочі. Фізичні умови зберігання на холоді. Визначання та вимірювання: ДСТУ ISO 2169-2003 - [Чинний від 2004.07.01]. - К.: Держспоживстандарт України, 2004. - 6 с.

15. Фрукти i овочі свіжі. Відбирання проб: ДСТУ ISO 874-2002. - [Чинний від 2003.10.01]. К.: Держспоживстандарт України, 2003. - 9 с.

16. Ящики из древесины и древесных материалов для продукции пищевых отраслей промышленности, сельского хозяйства и спичек. Технические условия: ГОСТ 10131-93. - [Введен в действие 01.07.95]. - М.: Стандартинформ, 2008. $-42 \mathrm{c}$.

17. Li H.Y. Effect of chitosan on incidence of brown rot, quality and physiological attributes of postharvest peach fruit / H.Y. Li, T. Yu // Journal of the Science of Food and Agriculture. - 2001. - P. 269274. 